\title{
Effect Work Discipline, Leadership and Motivation on Staff Performance in West Java Province Regional Development Office
}

\author{
Achmad Rizal* \\ Universitas Padjadjaran, \\ Emma Rochima \\ Universitas Padjadjaran \\ Mudiyati Rahmatunnisa \\ Universitas Padjadjaran \\ Cipta Endyana \\ Universitas Padjadjaran \\ *achmad.rizal@unpad.ac.id
}

\begin{abstract}
The performance was the result that was the goal in every organization to achieve its goals. Human resources have a vital position, considering its human resources' quality strongly influences the organization's performance. Besides, high-quality natural resources were useful in adjusting the movement of business climate change so quickly. Work discipline, leadership, and motivation were essential for a company to increase staff performance. This study aims to determine work discipline, leadership, and motivation on staff performance-associative research method with multiple linear analysis techniques. The study population amounted to 150 respondents; the sampling technique used purposive sampling, where the number of samples of 60 respondents was calculated using the Slovin formula. The study results show that simultaneously work discipline, leadership, and motivation significantly influence staff performance. Partially only work discipline and leadership have a significant effect, while a lack of motivation was significant for staff performance. As one of the determinants of direction and organizational goals, leaders should control work behaviors and direct them to staff job satisfaction.
\end{abstract}

Keywords: Work Discipline; Leadership; Motivation; Performance

\section{Introduction}

The advancement of technology and information in the current global era has spurred rapid changes in all aspects, including in an organization. Changes and developments in society as a result of globalization were conditions that cannot be avoided. The changes were intended to understand whether the administrative reform process means conducting a series of efforts that resulted in significant changes in management and organization, personal, administrative procedures, and the company (Abdullah, 2011; Poorhosseinzadeh \& Subramaniam, 2012; OniOjo, et al, 2015; Ibidunni, et al, 2016; Falola, et al, 2018; Rizal et al, 2020).

West Java actively cooperates with foreign government entities and private actors such as investors and entrepreneurs from many East Asia and Pacific, Middle East, Europe, Africa, and America. Throughout 2016 the foreign cooperation was dominated by countries in East Asia and the Pacific. In the trade sector, the West Java trade balance in general still recorded a deficit in early 2017, which was IDR.556.68 billion, but this figure decreased compared to the deficit at the end of 2016, IDR. 26.84 trillion (CSA, 2018).

This condition was due to the trade balance between regions always experiencing a deficit. At the same time, the foreign trade balance has consistently recorded a surplus since 
2014. At the beginning of 2017, West Java's overseas exports increased from IDR.44.93 trillion to IDR.46.64 trillion. The increase in the rate of growth of overseas exports was far higher than that of imports. Based on its share, the largest export commodity from West Java in 2017 was from the textile and textile products $(20.1 \%)$, followed by vehicles $(17.1 \%)$, electronics $(15.3 \%)$, and chemical $(7.5 \%)$. Excellent performance in foreign trade was mainly driven by improving all trade partner countries/regions, both in ASEAN and regional partner countries. Among all trade partner countries/regions, the highest growth was exported to ASEAN and East Asia, especially automotive products. Data from the West Java Central Statistics Agency (CSA), West Java, has 13 trading partners, including East Asian countries. To increase exports, the West Java local government was also active in inviting business people and associations, SMEs, and coordinating with Indonesian representatives and market sounding with investors, and actively developing overseas market cooperation and development networks through overseas exhibitions and promotions (CSA, 2018; CSA, 2019).

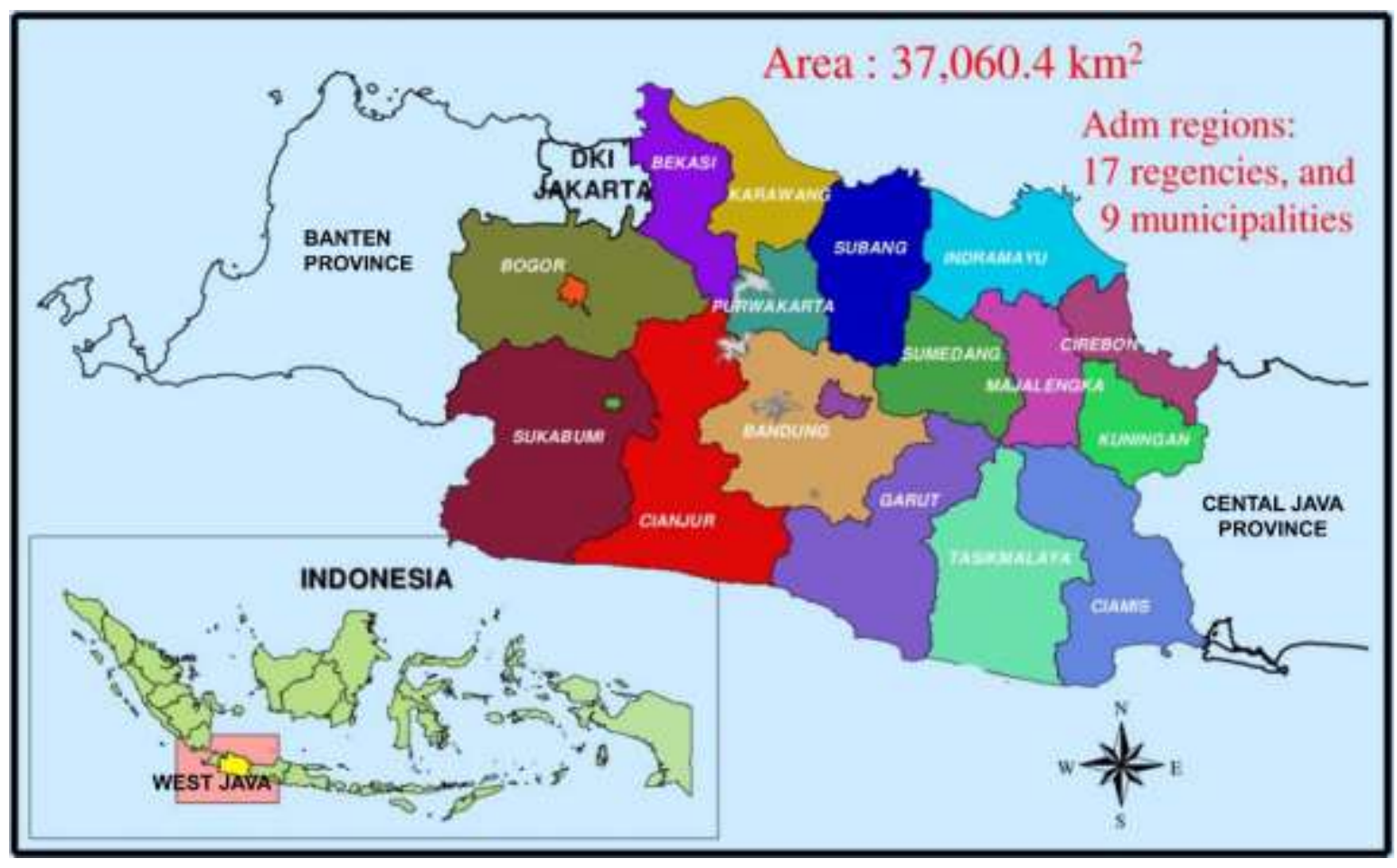

Figure 1. West Java Province Map (Rizal et al, 2020).

Based on the West Java Regional Government Implementation Report (RGIR) data in 2016, the realization of foreign investment in West Java was ranked number one at the national level, with the value of the foreign investment in West Java reach IDR.72.87 trillion. Besides, based on the Indonesian Investment Coordinating Board (IICB), in the investment sector in general, West Java was still the leading province of foreign investment in line with the many industries and industrial estates developed in West Java. Support for implementing the Economic Policy Package, especially in facilitating investment and licensing arrangements, was an attractive factor for foreign investment in West Java. Based on the West Java government's data, foreign investment in West Java was dominated by investors from East Asian countries like Japan, China, and Hong Kong. Foreign investment from Japan includes the automotive industry and the electronics industry. West Java's regional budgeting 
expenditure growth improved in 2017 along with the acceleration of strategic infrastructure project in West Java such as highway project Cileunyi - Sumedang - Dauwan (Cisumdawu), Soreang-Pasir Koja (Soroja) Toll Road, Cimanggis Cibitung Toll Road, Jakarta - Bandung high-speed rail, Airport International Kertajati, and LRT (CSA, 2018; CSA, 2019; Rizal, 2020).

The construction of this infrastructure also attracts new foreign investors. After West Java conducts market sounding, at least 40 investors from various countries want to invest in West Java. In attracting foreign investment to West Java, the West Java government established The West Java Incorporated (WJI) to increase economic competitiveness and create a conducive investment climate. The West Java government was also active in conducting foreign cooperation, including sister province cooperation with subnational governments of East Asian countries such as West Java Province - Shizuoka Prefecture (Japan), West Java Geyong Sangbuk Province (South Korea). Some cities in West Java also have sister city cooperation with countries in the East Asia Region such as Bogor - Shenzhen (China), Bandung - Suwon (South Korea), Bandung - Luzou (China), Bandung - Yingkou (China). During 20152018 several East Asian countries they were also conducting sister cities cooperation in West Java, such as Tainan (Taiwan), Kisarazu (Japan), Chongzuo Guangxi (China) with Bogor City, Hamamatsu (Japan) with Bandung. These collaborations encourage investment opportunities in various fields, not only economically but also socio-cultural and educational (CSA, 2018; CSA, 2019).

The West Java provincial office was one of Indonesia's regional governments has been active in international relations practice. West Java actively cooperates with foreign government entities and private actors such as investors and entrepreneurs from many East Asia countries. For organizations that provide services to the public or the community, staff performance can be seen from how they provide services to the community. This study was considered essential to work discipline, leadership, and motivation towards staff performance at The West Java provincial office.

\section{Literature review}

\section{Leadership Style}

Leadership style is a pattern of behavior designed in such a way as to influence subordinates to maximize the performance of their subordinates so that organizational performance and organizational goals can be maximized. Delery's research (2016) states that a leader must apply a leadership style to manage his subordinates because a leader will significantly affect the organization's success in achieving its goals. A good leader must hear the ideas and aspirations conveyed by his employees before making a decision.

\section{Motivation}

Motivation in organizational life, encouraging a form of morale for subordinates is essential to improve employee performance. Dhar (2015) states that motivation comes from the Latin word "movere", which means encouragement or giving a driving force that creates someone's work enthusiasm so that they are willing to work together, work effectively, and integrate with all their power and efforts to achieve satisfaction. According to Grissemann et al. (2013), motivation is a factor whose presence can lead to job satisfaction and improve employee performance. 
INOBIS: Jurnal Inovasi Bisnis dan Manajemen Indonesia

Volume 04, Nomor 01, Desember 2020

Achmad Rizal, Emma Rochima, Mudiyati Rahmatunnisa, Cipta Endyana

\section{Work Discipline}

Lee \& Hyun (2016) argues that discipline is an attitude, behavior, and actions following the company's regulations, both written and unwritten. The goals of work discipline, according to Lyria (2017), are as follows:

a. Employees have a high sense of concern for the achievement of company goals.

b. High morale, work passion, and employee initiative to carry out work

c. The amount of responsibility for employees to carry out their duties properly.

d. Develop a sense of belonging and a high sense of solidarity among employees.

e. Increased work efficiency and productivity of employees.

Based on the objective, employee work discipline must be enforced in an organization. Without good employee organizational support, it is difficult for the organization to achieve its goals. d. Employee Performance Every employee is required to make a positive contribution through good performance, considering that organizational performance depends on its employees' performance. Poorhosseinzadeh \& Subramaniam (2012), in their research, states that employee performance is work performance, namely the comparison between work results seen in real terms with the organization's work standards. Meanwhile, according to Carlborg et al. (2014), employee performance has been produced by individual employees. Ueno (2014) argues that employee performance is how much they contribute to the organization, which can be seen from the quality of work, attendance level, work completion period, cooperation with colleagues, and target achievement.

\section{Method}

The research method used in this research was associative research. Associative research aims to determine the influence of the relationship between two or more variables. The population in this study was the staff at The West Java provincial office, amounting to 150 people. Sampling was used as the non-probability method, namely purposive sampling. Prospective respondents have explained the indicators in the form of a statement that the research results of respondents obtained from the sample will represent the nature - the nature of the population.

Analysis Methods include: Classical Assumption Test Testing, classical assumptions made were (a) Normality test, Normality test aims to test whether, in the regression model, confounding variables or residuals have a normal distribution, (b) Multicollinearity Test for Multicollinearity Analysis If the VIF value was more than 10, it can be said that there was multicollinearity. (c)The heteroskedasticity test was used to determine whether the residual variant was not the same for all observations, which causes the estimator to be inefficient, and the coefficient of determination will be very high. If from observation, there were different variants, it was called heteroscedasticity. In other words, this test was intended to see the square of the distribution points of the regression line (De Jong, \& Vermeulen, 2006; Crossan \& Apaydin, 2010; Sofat, 2012; Chiang \& Hsieh, 2012; Ueno, 2014; Anna et.al, 2017).

Hypothesis Testing Hypothesis testing uses: (a) Multiple Linear Regression Analysis, Multiple linear regression analysis was a general statistical method used to examine the relationship between a dependent variable and several independent variables. (b) Correlation Coefficient (R) This analysis was used to measure the level of the relationship between the independent variable $(\mathrm{X})$ and the variable $(\mathrm{Y})$. (c) The coefficient of determination $\left(\mathrm{R}^{2}\right)$ The 
coefficient of determination was needed to measure how much influence the independent variable $(\mathrm{X})$ has on the dependent variable $(\mathrm{Y})$. (d) F test was used to test the independent variable regression coefficients' significance level on the dependent variable. (d) The t-test was used to test the effect of partially independent variables or each with the test criteria.

\section{Results and Discussion}

Human resources were the main factor in an organization. In achieving its objectives, an organization needs human resources as a system manager. For this system to work, its management must pay attention to several important aspects: leadership, motivation, work environment, performance, and other aspects. Those aspects will make human resource management an important indicator of effective and efficient organizational goals. The performance was the answer to the success or failure of the stated organizational goals, can be improved by providing an excellent example of a leader. The motivation was a staff's response to several statements regarding the overall business that arises from within the staff so that a growing urge to work and the desired goals can be achieved. And with high work discipline can affect him can work his work while working. Efforts to create excellent and effective performance in this office have not been optimal because several obstacles were faced. These constraints, such as staff absenteeism, where there was still staff who arrive late and leave early and even working hours, were often not visible (Lee \& Choi, 2003; By \& Dale, 2008; Delery, 2016; Lyria, 2017).

In the globalization context, transparency and human rights were central demands. No country escaped the wave of change. All countries, especially developing countries, face new challenges for change or renewal that will affect humanity's lives. Indonesia was one of the developing countries that were currently actively implementing development in all fields to go to a new Indonesia, national development. It was essential to realize a just and prosperous society in the Republic of Indonesia's Unitary State on Pancasila. The 1945 Constitution Development was carried out to improve all Indonesians' standard of living and welfare and lay a strong foundation for developing development covering the economic, socio-cultural, political, and security, and technology fields. The development of science and technology, which was characteristic of the globalization era, will exponentially change humans' way and lifestyle quickly. Human resource management was an essential aspect to support the sustainability of a company. In the organization or company setting, human resource management needs to be directed to a model that can attract all the potential of human resources for the benefit of the organization or in other words, the management of human resources must be directed at efforts that can explore the potential of human resources to make a positive contribution to the company or organization (Chang, et al, 2011; Chang, et al, 2011; Cadwallader et al, 2010; Carlborg et al, 2014; Rizal et al, 2018; Rizal \& Nurruhwati, 2019).

Competitive advantage will be achieved if the management can manage the heart of the company's activities by encouraging its human resources or better known as staffs, correctly and precisely, because basically, these staffs were an essential component for the company to create competitiveness that provides more quality for shareholders and customers in general. The success or failure of an organization in realizing its objectives depends significantly on its human resources. Although an organization has other useful resources, sophisticated work equipment, the right methods, and a large budget, if the human resources were not qualified and do not get serious management, the organization will experience difficulties in achieving its goals. This situation shows that human resources have an essential role in organizational growth and development because of the potential that exists in humans, such as talent, 
creativity, desire, and work activities (Davidson, et al., 2010; Chang, et al, 2011; Rizal et al, 2019).

\section{Multiple Linear Analysis}

Measure the level of the relationship between independent variables (X) and variables (Y). The correlation analysis results (r) obtained a value of 0.878 , which shows the relationship between work discipline and motivation with staff performance at The West Java provincial office was powerful at $87.8 \%$. The coefficient of determination of 0.771 was described to see the magnitude of all independent variables' contribution to the dependent variable. This figure shows the magnitude of independent variables' contribution to work discipline, leadership, and motivation on the dependent variable staff performance by $77.1 \%$, while the remaining $22.9 \%$ was caused by other factors not included in the model.

Table 1. Results of Multiple Linear Analysis

\begin{tabular}{|l|c|c|c|c|}
\hline \multicolumn{1}{|c|}{ Variable } & B & T-Test & Sig. & $\begin{array}{c}\text { Statistical } \\
\text { decision }\end{array}$ \\
\hline Constant & 1.437 & & & significant \\
\hline $\begin{array}{l}\text { Work discipline } \\
\text { (X1) }\end{array}$ & 0.458 & 4.861 & 0.000 & Significant \\
\hline Leadership (X2) & 0.415 & 3.812 & 0.000 & $\begin{array}{c}\text { Not } \\
\text { significant }\end{array}$ \\
\hline Motivation (X3) & 0.025 & 0.250 & 0.803 & \\
\hline
\end{tabular}

Source: Processed Data of Primary Data

Table 2. Results of Summary Statistical Test

\begin{tabular}{|l|c|c|c|}
\hline \multicolumn{1}{|c|}{ Coefficient } & Results & F-Test & Results \\
\hline R & 0.878 & F Tests & 62.730 \\
\hline R Square $\left(\mathrm{R}^{2}\right)$ & 0.771 & & \\
\hline $\begin{array}{l}\text { Adj R Square (Adj } \\
\mathrm{R}^{2}\end{array}$ & 0.758 & Sig. F & 0.000 \\
\hline
\end{tabular}

Source: Processed Data of Primary Data

$$
\mathrm{Y}=\mathrm{a}+\mathrm{b}_{1} \mathrm{X}_{1}+\mathrm{b}_{2} \mathrm{X}_{2}+\mathrm{b}_{3} \mathrm{X}_{3}+\varepsilon
$$

Staff performance: $1.437+0.458 \mathrm{X}_{1}+0.415 \mathrm{X}_{2}+0.025 \mathrm{X}_{3}+\mathrm{e}$

The multiple linear regression equation above can explain that:

1. a constant value of 1.437 means that if the variables of work discipline, leadership, and motivation were considered 0 (zero) or ignored, then staff performance at The West Java provincial office was 1.437 .

2. A value of $0.458 \mathrm{X} 1$ means that if the work discipline $\left(\mathrm{X}_{1}\right)$ increases by 1 unit, it increases staff performance at The West Java provincial office was 0.458 , assuming that other variables were considered constant or constant.

3. A value of $0.415 \mathrm{X} 2$ means that if the leadership variable $\left(\mathrm{X}_{2}\right)$ increases by 1 unit, it will also increase staff performance at The West Java provincial office was 0.415 , assuming that other variables were considered constant or constant.

4. Value of $0.025 \mathrm{X} 3$ means, if the motivation $\left(\mathrm{X}_{3}\right)$ increases by 1 unit, it will also increase staff performance at The West Java provincial office was 0.025 , assuming that other variables were considered constant or constant. 


\section{Hypothesis}

\section{Testing Hypothesis Simultaneously (F-Test)}

F-test to determine the effect of work discipline, leadership, and motivation on staff performance at The West Java provincial office then carried out the F test. Hypothesis testing simultaneously using F numbers. Testing was done by comparing the significant level of the calculation results with a significant level of $0.05(5 \%)$.

Table 3. Results of F-Test

\begin{tabular}{|c|c|c|c|}
\hline \multicolumn{2}{|c|}{ Model } & F & Sig \\
\hline 1 & Regression & 62.730 & $0.000^{\mathrm{b}}$ \\
\hline
\end{tabular}

Source: SPSS Data Processing Output

Dependent variable: STAFF PERFORMANCE

Simultaneous hypothesis testing results (F-Test) with a significant level (Sig) was 0.05 with a value of $F \quad 62.730$ greater than F table 3.94 with a significant level of 0.000 ; then, $\mathrm{H} 1$ was received. This description means that work discipline, leadership, and motivation affect staff performance at The West Java provincial office.

\section{Partial Hypothesis Test (t-test)}

Partial hypothesis testing was used to determine each variable's effect on work, leadership discipline, and motivation on staff performance at The West Java provincial office using the hypothesis test criteria as follows: $\mathrm{t}$-count $<\mathrm{t}$ table $(0.05)$, then $\mathrm{H} 0$ was accepted so that $\mathrm{H} 1$ was rejected. $\mathrm{t}$-count $>\mathrm{t}$ table $(0.05)$, then $\mathrm{H} 0$ rejected, and $\mathrm{H} 1$ accepted.

Table 4. Results of Test $t$

\begin{tabular}{|c|c|c|}
\hline Model & $\mathrm{t}$ & Sig \\
\hline (Constant) & 1.437 & 0.144 \\
\hline Work discipline & 0.458 & 0.000 \\
\hline Leadership & 0.415 & 0.000 \\
\hline Motivation & 0.025 & 0.803 \\
\hline
\end{tabular}

Source: SPSS Data Processing Output

The calculation result can be seen in table 4 . The results were as follows:

1. For variable work discipline $\left(X_{1}\right) \mathrm{t}$-value 4.861 greater than the value $\mathrm{t}$ table of 2.790 with a significant level of $0.000<\mathrm{a} 0.05$, $\mathrm{H} 0$ was rejected, and $\mathrm{H} 1$ accepted. Thus, work discipline affects staff performance at The West Java provincial office. 
2. For the leadership variable $\left(\mathrm{X}_{2}\right)$, the value of $\mathrm{t}$ arithmetic 3.812 was greater than the $\mathrm{t}$ table of 2.790 with a significant level of $0.000<\mathrm{a} 0.05$; then, $\mathrm{H} 0$ was rejected $\mathrm{H} 1$ was accepted. Thus, leadership influences staff performance at The West Java provincial office.

3. For the motivation variable $\left(\mathrm{X}_{3}\right)$, the value of $\mathrm{t}$-counts was 250 smaller than the table of 2.790 with a significant level of $0.803>\mathrm{a} 0.05$, so $\mathrm{H} 0$ was accepted, and $\mathrm{H} 1$ was rejected. Thus, motivation does not affect staff performance at The West Java provincial office.

\section{Discussion}

\section{Effect of Work discipline, Leadership, Motivation on Staff performance}

The study results show that simultaneously work discipline, leadership, and motivation significantly influence the official's performance of The West Java Province. One of the things that affect staff performance was discipline. Self-discipline was one of several factors that affect staff performance. Because without discipline, all activities that will be carried out will bring results that were less satisfactory and not in line with expectations. This factor can lead to a lack of achievement of the organization's goals and objectives and hamper the organizational program.

Dhar (2015) defines human resource management as a process of planning, organizing, directing, and supervising activities of procurement, development, compensation, integration, maintenance, and release of human resources to achieve individual goals, organization, and society. Jiang, et al, (2012) states that human resource management was the preparation and implementation of a coordinated plan to ensure that existing human resources can be utilized as well as possible to achieve organizational goals.

\section{Work discipline Staff performance}

The results of the study show that work discipline affects state performance at The West Java provincial office. Work discipline showed by staff also influences its performance. Because with good discipline by following company rules, staff can do their work on time and do not impede other company work fields.

Discipline was the capital needed to achieve the desired goals. Work discipline was essential in a company because an organization or agency will carry out its work programs to achieve the set goals in an atmosphere of discipline. Dotzel, et al (2013) defines discipline as a form of training that seeks to improve and shape staff knowledge, attitudes, and behavior to work cooperatively with other staff and improve work performance voluntarily. JiménezJiménez \& Sanz-Valle (2008) states that discipline was an attitude of respect, respect, obedience, and obedience to applicable regulations, both written and unwritten, capable of carrying it out and not dodging to accept sanctions if he violates the duties and authority given to him.

\section{The leadership of Staff Performance}

The results of the study show that leadership influences staff performance at The West Java provincial office. Many practitioners and management experts emphasize the importance of social roles in determining an institution's success (organization), both in the private and public sectors. 
Leadership was the essence of the organization's management, essential resources, and the central point of each office administration activity. So, leadership was a significant factor in driving and influencing leadership organizational performance. Flikkema, et al (2007) and Grissemann et al (2009) defines leadership as the process of influencing the activities of individuals or groups to achieve goals in certain situations. Gunday, et al (2011) and Grissemann et al (2009) suggests that leadership can influence a group towards achieving goals. These leadership indicators are operational as follows: Telling can tell members what they should do, Selling the ability to sell/give ideas to other members, participating, namely the Capacity of participating with members and Delegating, i.e., Capacity of delegate members.

\section{The motivation for Staff Performance}

Hu et al (2009) and Jiang, et al, (2012) states that motivation was a force that encourages staff who raises and directs behavior. Jiang, et al, (2012) defines motivation as a power that emerges from within or outside a person and arouses enthusiasm and perseverance to achieve something desired. Motivation workers will affect their productivity and channel organizational goals as part of a manager's duties. Unfortunately, occur otherwise the evidence research results show that motivation does not affect staff performance at The West Java provincial office. Motivation has a close relationship with attitudes and behavior possessed by someone. Attitudes in each individual interact with values, emotions, roles, social structure, and environment. Each individual has a different background and attitude towards existing stimuli, so that the motivation that appears in each individual was different.

This study found that motivation did not significantly influence staff performance. Increase staff work motivation so that it still needs to be improved. There is a strong indication that employees' motivation or work motivation to carry out their duties and work more efficiently is still relatively lacking, as seen in work enthusiasm and enthusiasm, work discipline, use of tools, materials and time, and other resources owned by the organization. The intrinsic motivation in nature, namely encouragement or stimulation that comes from the nature and content of the job or a reward that is directly generated from the performance of a job task, has not been optimally formed.

In general, the performance was a description of the organization achievements in operations. An organization needs humans as the primary supporting resources to achieve the stated goals (Leitner \& Guldenberg, 2010). Quality human resources will contribute to advancing the organization as a place to increase work productivity. The strategic position to increase organizational productivity was staff, namely individuals who work in an organization or company (Keegan \& Lucas, 2005; Koellinger, 2008; Gallouj \& Savona, 2009; Enz, 2009). Lee \& Hyun (2016) defines performance as the quality of work achieved by staff in carrying out their duties following their responsibilities. Staff performance can be measured by how much they contribute to the organization. The performance dimensions include quality, quantity, workplace presence, and cooperative attitude.

\section{Conclusion}

This study's conclusion was (1) Work discipline has a significant effect on staff performance at The West Java provincial office; (2) Leadership has a significant effect on staff performance at The West Java provincial office; (3) Motivation does not significantly influence staff performance at The West Java provincial office (4) The analysis results show that jointly 
work discipline, leadership, and motivation affect staff performance at The West Java provincial office.

The main finding was that staff-related work discipline, leadership, and motivation were crucial for provincial office performance, not only because of the direct effects. The indirect effects through staff characteristic of other types of performances, and other internal and external factors, on performance, were statistically significant, except for seasonality. At the same time, factor work discipline, leadership, and motivation directly influence staff performance, which underlines their importance. When both direct and indirect relationships are considered together, staff related to work discipline, leadership, and motivation have the most substantial positive total effects on provincial office performance. Further research needs to identify the precise types and combinations of staff-related work discipline, leadership, and motivation that most effectively support provincial office performance.

\section{References}

Abdullah, S. (2011) "Evaluation of Allen and Meyer's organizational commitment scale: a cross-cultural application in Pakistan”. J. Educ. Vocat. Res. 1 (3), 80-92.

Anna, Z. Suryana A.A.H. Maulina, I. Rizal, A. \& P Hindayani. (2017) "Biological parameters of fish stock estimation in Cirata Reservoir (West Java, Indonesia): A comparative analysis of bio-economic models". Biodiversitas Journal of Biological Diversity 18 (4) $1468-1474$.

By, R. T., \& Dale, C. (2008) "The successful management of organisational change in tourism SMEs: Initial findings in UK visitor attractions". International Journal of Tourism Research, 10(4), 305-313.

Cadwallader, S., Jarvis, C. B., Bitner, M. J., \& Ostrom, A. L. (2010) "Frontline employee motivation to participate in service innovation implementation". Journal of the Academy of Marketing Science, 38(2) 219-239.

Carlborg, P., Kindström, D., \& Kowalkowski, C. (2014) "The evolution of service innovation research: A critical review and synthesis". The Service Industries Journal, 34(5), 373398.

Chang, S., Gong, Y., \& Shum, C. (2011) "Promoting innovation in hospitality companies through human resource management practices". International Journal of Hospitality Management, 30(5) 812-818.

Chang, Y.-Y., Hughes, M., \& Hotho, S. (2011) 'Internal and external antecedents of SMEs' innovation ambidexterity outcomes". Management Decision, 49(10), 1658-1676.

Chiang, C.F., \& Hsieh, T.S. (2012) "The impacts of perceived organizational support and psychological empowerment on job performance: The mediating effects of organizational citizenship behaviour". International Journal of Hospitality Management, 31(1), 180-190.

Crossan, M. M., \& Apaydin, M. (2010) "A multi-dimensional framework of organizational innovation: A systematic review of the literature". Journal of Management Studies, 47(6), 1154-1191.

Central Statistics Agency (CSA). 2018 West Java Province in Number (Provinsi Jawa Barat Dalam Angka). West Java Central Statistics Agency.

Central Statistics Agency (CSA). 2019. West Java Province in Number (Provinsi Jawa Barat Dalam Angka). West Java Central Statistics Agency. 
Davidson, M. C. G., Timo, N., \& Wang, Y. (2010) "How much does labour turnover cost? A study of four- and five-star hotels". International Journal of Contemporary Hospitality Management, 22(4) 1-31.

De Jong, J. P. J., \& Vermeulen, P. M. (2006) "Determinants of Product Innovation in small firms. A Comparison across Industries”. International Small Business Journal, 24(6) 587-609.

Delery. J.E. (2016). "Human resource management practices and organizational effectiveness: internal fit matters", J. Organ. Effect.: People Perform 3 (2), 30-45.

Dhar, R. L. (2015) "The effects of high-performance human resource practices on service innovative behaviour". International Journal of Hospitality Management, 51, 67-75.

Dotzel, T., Shankar, V., \& Berry, L. L. (2013) "Service innovativeness and firm value". Journal of Marketing Research, 50(2) 259-276.

Enz, C. (2009) "Key issues of concern in the lodging industry: What worries managers". Cornell Hospitality Report, 9(4), 1-17.

Falola, H.O., Salau, O.P., Olokundun, A.M. Oyafunke-Omoniyi, C.O., A.S. Ibidunni, \& Oludayo, O.A. (2018) 'Employees' intrapreneurial engagement initiatives and its influence on organizational survival". Bus.: Theory Pract. 19, 9-16.

Flikkema, M., Jansen, P., \& Van der Sluis, L. (2007) "Identifying neo-Schumpeterian innovation in service firms". Economics of Innovation and New Technology, 16(7) 541558.

Gallouj, F., \& Savona, M. (2009) "Innovation in services: A review of the debate and a research agenda". Journal of Evolutionary Economics, 19(2), 149-172.

Gomezelj, D. O. (2016) "A systematic review of research on innovation in hospitality and tourism”. International Journal of Contemporary Hospitality Management, 28(3), 516558.

Grissemann, U., Plank, A., \& Brunner-Sperdin, A. (2013) "Enhancing business performance of hotels: The role of innovation and customer orientation". International Journal of Hospitality Management, 33(1), 347-356.

Gunday, G., Ulusoy, G., Kilic, K., \& Alpkan, L. (2011) "Effects of innovation types on firm performance". International Journal of Production Economics, 133(2), 662-676.

Hu, M.-L. M., Horng, J.-S., \& Sun, Y.-H. C. (2009) "Hospitality teams: Knowledge sharing and service innovation performance". Tourism Management, 30(1), 41-50.

Ibidunni, O.S. Osibanjo, A.O. Adeniji, A.A. Salau, O.P. \& Falola, H.O. (2016) "Talent retention, and organizational performance: a competitive positioning the Nigerian banking sector, Period". Polytech. Soc Manag. Sci. 24 (1) 1-13.

Jiang, K., Lepak, D. P., Hu, J., \& Baer, J. C. (2012) "How does human resource management influence organizational outcomes? A meta-analytic investigation of mediating mechanisms". Academy of Management Journal, 55(6), 1264-1294.

Jiménez-Jiménez, D., \& Sanz-Valle, R. (2008) "Could HRM support organizational innovation?". International Journal of Human Resource Management, 19(7), 12081221.

Keegan, S. N., \& Lucas, R. (2005) "Hospitality to hostility: Dealing with low response rates in postal surveys". International Journal of Hospitality Management, 24(2) 157-169.

Koellinger, P. (2008) "The relationship between technology, innovation and performance: Empirical evidence from E-Business in Europe". Research Policy, 37(8), 1317-1328.

Lee, H. \& Choi. B. (2003). "Knowledge Management Enablers, Processes, and Organizational Performance: An Integrative View and Empirical Examination”. J. Manag. Inf. Sys. 20 (1), 179-228. 
Lee, K.-H., \& Hyun, S. S. (2016) "An extended model of employees' service innovation behavior in the airline industry". International Journal of Contemporary Hospitality Management, 28(8), 1622-1648.

Leitner, K. L., \& Guldenberg, S. (2010) "Generic strategies and firm performance in SMEs: A longitudinal study of Austrian SMEs". Small Business Economics, 35, 169-189.

Li, M., \& Hsu, C. H. C. (2016) "A review of employee innovative behavior in services". International Journal of Contemporary Hospitality Management, 28(12), 2820-2841.

Lyria. R.K. (2017) "Role of Talent Management on Organization Performance in Companies Listed in Nairobi Security Exchange in Kenya: Jomo Kenyatta University of Science and Technology". International, J. Humanit. Soc. Sci. 3 (21) 285-290.

Oni-Ojo, E.E. Salau, O.P. Dirisu, J.I. \& Waribo, Y.J. (2015) "Incentives and job satisfaction: its implications for competitive positioning and organizational survival in Nigerian manufacturing industries", Am. J. Manag. 15 (2), 74-87.

Poorhosseinzadeh, M.I.D. \& Subramaniam. (2012) "Determinants of successful talent management in MNCs in Malaysia", J. BasicAppl. Sci. Res. 2, 12-24.

Rizal, A \& Nurruhwati, I. (2019) "Analysis of the effect of city growth on the development of the hinterland region In Cianjur Regency". World Scientific News, 115, 260-26.

Rizal, A. Andriani, Y. \& Kusumartono, F.X. (2019) "A Strategic Environmental Assessment for Southern Coastal of West Java Province, Indonesia". World Scientific News 137 188-209.

Rizal, A., Apriliani, I M. \& Permana R. (2020) “Assessment the Impact of Fiscal and Monetary Policy on West Java Province of Indonesia: A Computable General Equilibrium Analysis". World scientific news 150, 162-181.

Rizal, A Dhahiyat, Y Andriani, Y Handaka, AA \& Sahidin, A. (2018) "The economic and social benefits of an aquaponic system for the integrated production of fish and water plants". IOP Conference Series: Earth and Environmental Science, 137 (1) 012098

Sofat, S. (2012) "Effect of motivation on employee performance and organizational productivity, BIZ N. BYTES-Q”. Publ. J. Appl.Manag. Comput. Sci. 15 (6), 79-90.

Ueno. (2014) "Developing a conceptual model illustrating how HRM practices support each other in order to improve service quality", Procedia - Soc, Behav. Sci. 14 (8) 24-31. 